\title{
Download
}

UDC 911.3 https://doi.org/10.17721/2308-135X.2021.63.3-15

Lyubitseva Olha Olexandrivna, Doctor of Geographical Sciences, Professor Taras Shevchenko National University of Kyiv, Kyiv, Ukraine,

e-mail: loa_13@ukr.net, ORCID ID: 0000-0002-8508-9395

Smyrnov Igor Georgiyovych, Doctor of Geography Sciences, Professor Taras Shevchenko National University of Kyiv, Kyiv, Ukraine,

e-mail: smyrnov_ig@ukr.net, ORCID ID:0000-0002-6395-7251

\section{PROBLEMS OF TOURISM AND HOSPITALITY DEVELOPMENT IN THE CONDITIONS OF THE COVID 19 PANDEMIC: WORLD AND UKRAINIAN TRENDS}

The aim of the article is to reveal the changes and problems that have arisen in the field of tourism and hospitality in the world and in Ukraine as a result of the impact of the Covid-19 pandemic and ways to solve these problems.

Research methodology. That's author's analysis of materials of the current World and Ukrainian press, which reflected the actual state of the problem and new phenomena in the field of tourism and hospitality of the world and Ukraine. The article is based on the results of research and reflections of the authors on the impact of the pandemic on tourism and hospitality fields, taking into account world and Ukrainian experience [1], as well as on the author's analysis of current Ukrainian press publications on current changes in 2020-2021 in in the field of tourism 
and hospitality in the world and in Ukraine during the implementation of measures to combat the destructive effects of the pandemic on travel industry [2-10].

Results of the research. Problems, changes, new phenomena in the field of tourism and hospitality of the world and Ukraine during the pandemic and quarantine restrictions in travel in the field of domestic and international tourism were identified. The Covid-19 pandemic, which suddenly "fell" on world tourism in 2020-2021, not only slowed down its development, including in Ukraine, but also caused significant changes in the entire field of tourism and hospitality. The essence of these changes is revealed, which included not only "minuses", but also certain "pluses".

Practical significance. Is to identify problems of tourism and hospitality during the Covid-19 pandemic in 2020-2021 in Ukraine and the world and ways out of the crisis of the travel industry, taking into account the experience of other countries and features of solving the above problems in tourism, hotel and restaurant industry in Ukraine. Thus, the introduction and disclosure of the essence of new phenomena in world tourism and hospitality (travel shaming, workcation, work from hotel, staycation, digital nomads, travel bubbles) led to their use in the practice of tourism in Ukraine, for example, in hotels of Lviv.

Keywords: tourism, hotel and restaurant business, Covid-19 pandemic, lockdown, UNWTO, Ukraine, Kyiv, travel shaming, workcation, work from hotel, staycation, digital nomads, travel bubbles.

References

1. Lyubiceva O.O. «Nema togo zlogo, shhob ne vy'jshlo na dobre» abo pozytyvni vysnovky z pandemiyi. Turyzm u XXI stolitti: vyklyky ta reaguvannya: materialy mizhn.nauk.prakt.konf. $-\mathrm{K}$., 2020. S.123-127.

2. Savyna Y. Slovar puteshestvennyka vremen pandemyy. Vesti. 2020. 3 dekabrya. S.11.

3. Savyna Y. Puteshestvye - 2021: chto vazhno znat. Vesti.2020. 8 dekabrya. S.8. 
4. Mychkovskaya N. V karantyn kafe y restorany staly udobnimy «kozlamy otpushhenyya». KP v Ukrayne. 2020. 6-13 avgusta. S.7.

5. Mylynevskyj N. Skoro uvydym val zakrytyj restoranov. Vesti. 2020. 28 iyulya. S.10.

6. Kasyanova Y. Tajnoe logovo vlasty. Vesti. 2020. 6 avgusta. S.14.

7. Drannyk A. Teatry v kvartyrax y vecherynky na strojkax. Vesti.2020. 20 noyabrya. S.5.

8. Kasyanova Y. Salo y borshh bolshe ne $v$ mode. Pochemu $v$ Ukrayne massovo zakrbvayutsya ukraynskye restorany. Vesti. 2020. 17 sentyabrya. S.6.

9. Drannyk A., Kasyanova Y. Ix smyl karantyn. Vesti. 2021. 11 fevralya. S.8.

10. Kasyanova Y. «My uzhe pered vyborom, kogo spasat». Vesti. 2021. 19 marta. S.5.

11. Kruglykov D. «Poterya polovyny vyruchky». S kakymy ubytkamy stolknulsya byznes. // Vesti 2021. 2 aprelya. S. 6.

12. UNWTO Launches a Call for Action for Tourism's COVID-19 Mitigation and Recovery | UNWTO//UNWTO Launches a Call for Action for Tourism's COVID-19 Mitigation and Recovery | UNWTO

13. UNWTO Tourism Recovery Tracker//UNWTO Launches a Call for Action for Tourism's COVID-19 Mitigation and Recovery | UNWTO 
v631

Written by Administrator

Friday, 28 January 2022 09:25 - Last Updated Thursday, 14 July 2022 10:37 